\title{
Penghambatan produksi enzim eksoprotease Aeromonas hydrophila oleh ekstrak rimpang temu lawak (Curcuma xanthorrhiza Roxb.)
}

\author{
Inhibition of exoprotease production in Aeromonas hydrophila by rhizome \\ extract of temu lawak (Curcuma xanthorrhiza (Roxb.))
}

\author{
UMI LESTARI, ARTINI PANGASTUTI, ARI SUSILOWATI \\ Jurusan Biologi, Fakultas Matematika dan Ilmu Pengetahuan Alam, Universitas Sebelas Maret. Jl. Ir. Sutami 36A, \\ Surakarta 57126. Tel./Fax. +62-271-663375.
}

Diterima: 28 Desember 2005. Disetujui: 10 Maret 2006.

\begin{abstract}
Conventional treatment of infectious diseases is based on compounds that kill or inhibit the growth of bacteria. A major concern with this approach is the systematic development of resistance to antimicrobial compounds. The discovery of communication (quorum sensing system) regulating bacterial virulence opens up ways to control specific bacterial infectious without interfering with the growth. The fish pathogen Aeromonas hydrophila produces a quorumsensing signal, N-Butanoyl-L-Homoserine Lactone (C4-HSL). C4-HSL regulates exoprotease synthesis, a virulence factor of $A$. hydrophila. Expression of exoprotease can be blocked by using a quorum sensing inhibitor. The purpose of this study was to investigate the inhibiting effect of Curcuma xanthorrhiza (Roxb.) extract on exoprotease production of $A$. hydrophila. Extraction was conducted by using $n$-hexane, ethyl acetate, and ethanol. The qualitative exoprotease assay result showed that $\mathrm{n}$-hexane extract of $C$. xanthorrhiza did not affect the growth and exoprotease production of $A$. hydrophila. Meanwhile, $4 \%$ of ethyl acetate and ethanol extract of $C$. xanthorrhiza could inhibit exoprotease production without affecting $A$. hydrophilla growth. The quantitative exoprotease assay result showed that $4 \%$ of ethyl acetate and ethanol extract could inhibit the exoprotease production by $93,9 \%$ and $95,6 \%$. The growth of $A$. hydrophila was not affected by this extract.
\end{abstract}

Keywords: Aeromonas hydrophila, Curcuma xanthorrhiza (Roxb.), exoprotease production, inhibit

\section{PENDAHULUAN}

Aeromonas hydrophila merupakan bakteri yang menyebabkan penyakit pada ikan (Swann and White, 2002). Penyakit yang disebabkan oleh $A$. hydrophila dinamakan Motile Aeromonad Septicemia (MAS) (Roberts, 1993). Aeromonas hydrophila ditemukan paling banyak di perairan tawar. Hampir seluruh ikan air tawar rentan terhadap penyakit yang diakibatkan oleh bakteri ini (Noga, 1995). Menurut Afrianto (1992), penyakit yang disebabkan oleh A. hydrophila pada ikan budi daya menimbulkan kerugian yang sangat besar, sehingga perlu adanya penanganan yang efektif.

Salah satu faktor virulensi ekstraseluler yang disekresikan oleh $A$. hydrophila adalah enzim eksoprotease. Enzim ini bersifat proteolitik karena dapat mendegradasi albumin, kasein, fibrinogen, dan gelatin, sehingga $A$. hydrophila berpotensi sebagai patogen pada ikan (Schotts et al., 1985). Menurut Ellis et al. (1981), aktivitas enzim eksoprotease berkorelasi dengan terjadinya infeksi.

Produksi enzim eksoprotease A. hydrophila dikontrol oleh suatu molekul sinyal $N$-butanoyl-Lhomoserine lactone (C4-HSL). Senyawa ini juga berfungsi sebagai alat komunikasi interseluler pada bakteri yang disebut sistem quorum sensing. Melalui sistem quorum sensing, bakteri dapat mendeteksi keberadaan bakteri lain serta jumlahnya di lingkungan dan sebaliknya. Ketika hanya satu sel yang mensekresikan molekul C4-HSL ke lingkungan maka konsentrasinya sangat rendah, namun apabila populasi bakteri telah mencapai kepadatan tertentu atau telah memenuhi quorum maka C4-HSL yang disekresikan ke lingkungan juga meningkat sehingga mampu mengaktifkan gen penyandi enzim eksoprotease $A$. hydrophila yang berperan sebagai faktor virulensi (De Kievit and Iglewski, 2000).

Sebelum ditemukan sistem quorum sensing yang berperan dalam ekspresi faktor virulensi, pencegahan infeksi dilakukan dengan menggunakan senyawa antibiotik yang dapat membunuh atau menghambat pertumbuhan bakteri tersebut (Hentzer and Givskov, 2003). Penggunaan senyawa tersebut secara terus-menerus dapat meningkatkan frekuensi mutasi yang dapat menghasilkan generasi bakteri yang resistan (Lewis, 2001). Dengan pengetahuan mengenai sistem quorum sensing, dapat dikembangkan suatu cara pengendalian bakteri penyebab penyakit pada ikan yang tidak hanya terbatas pada pemberantasan bakteri atau antibiosis. Pengendalian infeksi dapat dilakukan dengan mencegah pengumpulan massa bakteri atau dengan merusak sistem komunikasi interseluler 
bakteri dan membiarkan bakteri tetap hidup bersama selama perilakunya tidak destruktif (Suwanto, 2005).

Sistem quorum sensing dapat dijadikan target terapi antimikrobial. Penghambatan komunikasi antar sel tersebut dapat menurunkan patogenisitas suatu bakteri (De Kievit and Iglewski, 2000). Beberapa senyawa diketahui dapat menghambat sistem quorum sensing. Ekstrak alga Flustra foliacea dapat menghambat aktivitas molekul $\mathrm{N}$-AcylHomoserine Lactone pada Pseudomonas aeruginosa tanpa mengganggu pertumbuhannya. Akibatnya, produksi enzim eksoprotease $P$. aeruginosa menurun (Peters et al., 2003). Senyawa furanon yang diisolasi dari alga Delisea pulchra juga dapat menghambat sistem quorum sensing pada bakteri Vibrio fischeri dan Vibrio harveyi (Rice et al., 1999). Selain itu, senyawa curcumin yang diisolasi dari Curcuma domestica juga dapat menghambat sistem quorum sensing pada Chromobacterium violaceum (Rukayadi and Hwang, 2004). Penelitian ini diharapkan dapat dijadikan sebagai dasar pencarian obat atau senyawa yang dapat menghambat sistem quorum sensing tanpa harus membunuh bakteri.

Rimpang temu lawak (Curcuma xanthorrhiza (Roxb.)) mengandung berbagai senyawa yang berpotensi sebagai agen kemoterapeutik. Salah satu senyawa tersebut adalah curcumin yang telah terbukti mampu menghambat sistem quorum sensing pada Chromabacterium violaceum. Pengetahuan tersebut dapat dijadikan sebagai dasar untuk dilakukan penelitian untuk menghambat sistem quorum sensing pada $A$. hydrophila dengan menggunakan ekstrak rimpang $C$. xanthorrhiza.

Penghambatan sistem quorum sensing pada $A$. hydrophila dapat dibuktikan dengan adanya penurunan produksi enzim eksoprotease yang dihasilkan. Produksi enzim eksoprotease dapat diketahui dengan mengukur aktivitasnya. Oleh karena itu perlu diadakan penelitian untuk mengukur aktivitas enzim eksoprotease dari $A$. hydrophila setelah pemberian agen kemoterapeutik berupa ekstrak $C$. xanthorrhiza dengan pelarut nhexan, etil asetat, dan etanol. Pelarut-pelarut tersebut digunakan untuk mengekstrak senyawasenyawa non polar, semi polar, dan polar yang terkandung pada rimpang $C$. xanthorrhiza.

Tujuan penelitian ini adalah untuk mengetahui adanya aktivitas penghambatan produksi enzim eksoprotease $A$. hydrophila oleh ekstrak rimpang $C$. xanthorrhiza dengan pelarut n-hexan, etil asetat, dan etanol, serta mengetahui jenis ekstrak yang memiliki kemampuan paling besar dalam menghambat produksi enzim eksoprotease $A$. hydrophila.

\section{BAHAN DAN METODE}

\section{Tempat dan Waktu Penelitian}

Penelitian dilakukan pada bulan Juni sampai November 2005 di Sub Laboratorium Biologi,
Laboratorium Pusat MIPA Universitas Sebelas Maret, Surakarta.

\section{Alat dan Bahan}

Alat yang digunakan dalam penelitian ini meliputi: (a) alat untuk ekstraksi yaitu blender, timbangan elektrik, rotary evaporator, hot plate, freezer, erlenmeyer, beaker glass, aluminium foil, dan kertas saring; (b) alat untuk pemeliharaan kultur, pengukuran pertumbuhan, dan pengukuran aktivitas enzim eksoprotease, yaitu spektrofotometer, shaker, mikropipet dan tip, laminar air flow, tabung reaksi, cawan petri, jarum ose, erlenmeyer, pinset, kertas saring, dan hot plate; serta (c) alat sterilisasi berupa autoclave.

Sementara itu, bahan yang digunakan meliputi: (a) rimpang $C$. xanthorrhiza yang diperoleh dari daerah Wonogiri; (b) kultur murni $A$. hydrophila yang diperoleh dari Laboratorium Penyakit Ikan (Fish Disease) Jurusan Teknologi Perikanan, Universitas Gadjah Mada, Yogyakarta, A. hydrophila diisolasi dari ikan lele (Clarias batrachus) yang sakit; (c) medium Luria-Bertani broth (LB Broth), Luria-Bertani agar (LB), azocasein, susu skim, Trichloro Acetic Acid (TCA), NaOH, dan buffer fosfat $\mathrm{pH} 7$; serta (d) pelarut $\mathrm{n}$-heksan, etil asetat, dan etanol.

\section{Cara Kerja}

\section{Pembuatan Serbuk Rimpang C. xanthorrhiza}

Rimpang $C$. xanthorrhiza dicuci bersih, kemudian diiris tipis dan dikeringkan di bawah sinar matahari secara tidak langsung. Irisan rimpang yang sudah kering diblender menjadi serbuk dan disimpan dalam wadah tertutup. Serbuk akan digunakan untuk pembuatan ekstrak rimpang $C$. xanthorrhiza dengan pelarut $n$-hexan, etil asetat, dan etanol.

\section{Pembuatan Ekstrak Rimpang C. xanthorrhiza}

Ekstraksi dilakukan dengan metode maserasi bertingkat dengan pelarut $n$-heksan, etil asetat, dan etanol yang bersifat non polar, semi polar, dan polar. Serbuk rimpang C. xanthorrhiza dilarutkan dalam n-heksan (100 mg serbuk/100 ml n-heksan), dikocok, dan dibiarkan selama 24 jam. Ekstrak disaring dan diambil filtratnya. Selanjutnya, ampas dilarutkan dalam pelarut etil alkohol, dikocok, dan dibiarkan selama 24 jam. Ekstrak disaring dan diambil filtratnya, ampasnya dilarutkan dengan etanol, dikocok, dan dibiarkan selama 24 jam. Masing-masing filtrat dipekatkan dalam rotary evaporator hingga diperoleh ekstrak kental (Harmani dkk., 2001).

\section{Pemeliharaan Kultur}

Aeromonas hidrophila ditumbuhkan pada medium agar miring NA dan diinkubasi pada suhu $37^{\circ} \mathrm{C}$ selama 24 jam. Setelah tumbuh sebagai biakan, $A$. hydrophila pada agar miring disimpan pada lemari pendingin $\left(4^{\circ} \mathrm{C}\right)$ sebagai stok biakan. 
Medium yang digunakan adalah Luria-Bertani (LB) agar yang ditambah dengan $2 \%$ susu skim. Sterilisasi medium dilakukan dengan menggunakan autoclave pada suhu $121^{\circ} \mathrm{C}$ selama 15 menit, sedangkan sterilisasi susu skim dilakukan pada suhu $110^{\circ} \mathrm{C}$ selama 30 menit.

Selanjutnya disiapkan cawan petri berisi $16 \mathrm{ml}$ medium dan ditambah dengan ekstrak n-heksan, ekstrak etil asetat, dan ekstrak etanol rimpang $C$. xanthorrhiza dengan konsentrasi 2\%,4\%,6\%, 8\%, dan $10 \%$ serta konsentrasi $0 \%$ sebagai kontrol negatif, dengan asumsi pada variasi konsentrasi tersebut produksi enzim eksoprotease dapat terhambat tanpa menghambat pertumbuhan $A$. hydrophila. Adapun untuk kontrol positif, pada medium LB agar ditambah dengan pelarut n-hexan, etil asetat, dan etanol.

Isolat $A$. hydrophila diinokulasikan pada cawan petri yang telah berisi medium padat dengan menggunakan jarum ose dan diinkubasi pada suhu $30^{\circ} \mathrm{C}$ selama 24 jam. Produksi enzim eksoprotease dapat dilihat dengan adanya zona bening pada medium. Zona bening terbentuk karena adanya aktivitas proteolitik dari enzim eksoprotease (Swift et al., 1999).

\section{Pengukuran Pertumbuhan Bakteri dan Pengujian}

Produksi enzim eksoprotease dapat diketahui dengan mengukur aktivitas enzim tersebut. Pengujian aktivitas enzim eksoprotease $A$. hydrophila secara kuantitatif dapat dilakukan dengan metode spektrofotometri. Prinsip pengujian aktivitas enzim eksoprotease berdasarkan pada pendapat Hanlon and Hodges (1981), yaitu kemampuan enzim protease untuk menghidrolisis azocasein. Residu azocasein yang tidak dapat dihidrolisis oleh enzim protease akan diendapkan oleh trichloro acetic acid (TCA). Endapan dipisahkan dan filtrat akan membentuk warna apabila direaksikan dengan $\mathrm{NaOH}$. Intensitas warna yang terbentuk diukur dengan spektrofotometer pada panjang gelombang $440 \mathrm{~nm}$.

Pengujian secara kuantitatif hanya dilakukan pada ekstrak yang menunjukkan pengurangan aktivitas proteolitik, ditandai dengan adanya pengurangan luas zona bening jika dibandingkan dengan kontrol. Isolat $A$. hydrophila berumur 24 jam ditumbuhkan pada $200 \mathrm{ml}$ LB broth yang telah ditambah dengan ekstrak rimpang $C$. xanthorrhiza, dan untuk kontrol negatif tidak ditambah dengan ekstrak rimpang $C$. xanthorrhiza, sedangkan untuk kontrol positif pada medium LB broth ditambah dengan pelarut, selanjutnya isolat diinkubasi pada suhu $30^{\circ} \mathrm{C}$ dan dikocok dengan shaker.

Mulai jam ke-0 dan selanjutnya setiap 2 jam selama 24 jam, $10 \mathrm{ml}$ suspensi bakteri diambil dan diukur pertumbuhannya menggunakan spektrofotometer pada panjang gelombang $600 \mathrm{~nm}$ sehingga diketahui nilai OD (optical density). Setelah diukur pertumbuhannya, suspensi bakteri disentrifugasi pada kecepatan $10.000 \mathrm{rpm}$ selama 10 menit. Satu mililiter filtrat kemudian dimasukan ke tabung reaksi yang telah berisi $3 \mathrm{ml}$ larutan buffer fosfat ( $\mathrm{pH}$ 7). Campuran ini kemudian dihangatkan hingga suhunya mencapai $37^{\circ} \mathrm{C}$. Sementara itu, $2 \mathrm{ml}$ azocasein dipanaskan pada penangas air hingga suhunya mencapai $37^{\circ} \mathrm{C}$ dan ditambahkan ke dalam campuran filtrat dan buffer fosfat, lalu diinkubasi selama 30 menit pada suhu $37^{\circ} \mathrm{C}$. Selanjutnya, campuran filtrat ditambah dengan $4 \mathrm{ml}$ trichloro acetic acid (TCA) sehingga terbentuk endapan kuning yang dipisahkan dengan penyaringan menggunakan kertas Whatman no. 1 atau disentrifugasi. Lima mililiter filtrat diambil dan ditambah dengan $5 \mathrm{ml}$ larutan $\mathrm{NaOH}$ 0,5 M sebelum diukur absorbansinya pada panjang gelombang 440 $\mathrm{nm}$.

Satu unit aktivitas enzim eksoprotease didefinisikan sebagai jumlah enzim yang dapat menghasilkan kenaikan pengukuran absorbansi sebesar 0,01 setiap jam pada kondisi pengukuran. Unit aktivitas enzim eksoprotease yang digunakan dalam penelitian ini dinyatakan dalam $\mathrm{U} / \mathrm{ml}$, dan ditetapkan dengan rumus:

$\mathrm{U} / \mathrm{ml}=($ absorbansi/0,01) $\times 2=$ unit aktivitas $/ \mathrm{ml}$ sampel (Hanlon and Hodges, 1981).

\section{Analisis Data}

Hasil pengukuran aktivitas enzim eksoprotease A. hydrophila dinyatakan dalam unit aktivitas $/ \mathrm{ml}$ sampel $(\mathrm{U} / \mathrm{ml})$ pada masing-masing perlakuan, kemudian dibandingkan dengan aktivitas enzim eksoprotease pada kontrol dan penurunannya yang dinyatakan dalam persentase.

\section{HASIL DAN PEMBAHASAN}

\section{Produksi Enzim Eksoprotease Aeromonas hydrophila}

Aeromonas hydrophila yang digunakan dalam penelitian ini diisolasi dari ikan lele ( $C$. batrachus) yang sakit. Dengan demikian, diharapkan $A$. hydrophila telah memproduksi faktor-faktor virulensi, di antaranya enzim eksoprotease. Menurut de Figuiredo and Plumb dalam Angka (2001), isolat A. hydrophila yang diisolasi dari ikan sakit lebih virulen daripada isolat yang diisolasi dari perairan.

Besarnya jumlah enzim yang diproduksi oleh suatu mikroorganisme tidak dapat diukur secara langsung. Jumlah enzim yang diproduksi tersebut biasanya sangat kecil. Menurut Murray et al. (1997), aktivitas katalisis yang dimiliki oleh suatu enzim memungkinkan untuk mengukur jumlah enzim yang diproduksi oleh suatu mikroorganisme.

Produksi enzim eksoprotease $A$. hydrophila dapat diketahui, baik secara kualitatif maupun kuantitatif. Secara kualitatif, produksi enzim eksoprotease dapat diketahui dari terbentuknya zona bening pada medium di sekitar biakan $A$. hydrophila. Medium yang digunakan adalah medium Luria Bertani Agar (LB Agar) yang ditambah dengan $2 \%$ susu skim. Aktivitas katalisis dari enzim eksoprotease menyebabkan terbentuknya zona bening. Menurut Poernomo dan Purwanto (2001), enzim 
eksoprotease akan menghidrolisis ikatan peptida protein susu skim menjadi bentuk yang lebih sederhana, yaitu asam amino. Selanjutnya, asam amino akan masuk ke dalam sel bakteri dan digunakan sebagai nutrisi. Meskipun secara umum enzim eksoprotease berperan dalam penyediaan nutrisi, namun menurut Leung and Stevenson (1988), pada $A$. hydrophila enzim eksoprotease berperan penting dalam menyebabkan kerusakan jaringan pada ikan. Produksi enzim eksoprotease $A$. hydrophila dapat dilihat pada Gambar 1.

Secara kuantitatif, produksi enzim eksoprotease A. hydrophila dapat diketahui dengan cara mengukur aktivitasnya dalam mendegradasi senyawa azocasein. Pengukuran aktivitas enzim eksoprotease dapat dilakukan dengan metode spektrofotometri. Menurut Hanlon and Hodges (1981), dari nilai absorbansi filtrat hasil degradasi azocasein oleh enzim eksoprotease dapat diperoleh nilai unit aktivitas enzim.

\section{Penghambatan produksi enzim eksoprotease Aeromonas hydrophila}

Sintesis enzim eksoprotease $A$. hydrophila diregulasi oleh sistem quorum sensing (Swift et al., 1999). Penghambatan sistem quorum sensing dapat menyebabkan produksi enzim eksoprotease menurun, akibatnya patogenisitas $A$. hydrophila juga akan berkurang. Penghambatan sistem quorum sensing dapat dijadikan sebagai suatu cara baru untuk mencegah penyakit yang disebabkan oleh bakteri tanpa harus menghambat pertumbuhan bakteri tersebut. Menurut Peters et al. (2003), pencegahan penyakit yang diakibatkan oleh bakteri dengan cara menghambat sistem quorum sensing dapat mengurangi berkembangnya resistensi bakteri oleh zat-zat antimikrobia.

Menurut Hentzer and Givskov (2003), sistem quorum sensing dapat dijadikan target penghambatan senyawa-senyawa kemotherapeutik. Pada penelitian ini, senyawa kemotherapeutik yang diduga dapat menghambat produksi enzim eksoprotease adalah ekstrak rimpang C. xanthorrhiza. Rimpang C. xanthorrhiza mengandung berbagai jenis senyawa aktif yang pengelompokannya didasarkan pada tingkat kepolaran senyawa-senyawa aktif tersebut. Menurut Chu (2005), ada tiga jenis kelompok senyawa aktif dalam rimpang $C$. xanthorrhiza, yaitu senyawa polar, senyawa semipolar, dan senyawa nonpolar. Untuk mendapatkan senyawa-senyawa yang terkandung dalam rimpang C. xanthorrhiza, dilakukan ekstraksi bertingkat dengan menggunakan pelarut nonpolar, semipolar, dan polar yaitu n-hexan, etil asetat, dan etanol. Salah satu senyawa semipolar yang diduga dapat menghambat sistem quorum sensing adalah curcumin. Pada penelitian yang dilakukan oleh Rukayadi and Hwang (2004) membuktikan bahwa curcumin dapat menghambat sistem quorum sensing pada Chromabacterium violaceum yang memiliki molekul sinyal C4-HSL.

Menurut penelitian yang dilakukan oleh Swift et al. (1999), penghambatan sistem quorum sensing untuk mengontrol virulensi dan mencegah infeksi $A$. hydrophila dapat dilakukan dengan menambahkan senyawa analog C4-HSL pada kultur $A$. hydrophila. Penghambatan produksi enzim eksoprotease $A$. hydrophila secara kualitatif dapat diketahui dari tidak terbentuknya atau berkurangnya luas zona bening di sekitar biakan $A$. hydrophila, sedangkan secara kuantitatif, produksi enzim eksoprotease dianggap terhambat apabila nilai unit aktivitas enzim mengalami penurunan. Selama proses pengujian aktivitas enzim eksoprotease $A$. hydrophila secara kuantitatif, pengukuran pertumbuhan $A$. hydrophila harus dilakukan, karena terkait dengan tujuan dari penelitian ini yaitu menghambat produksi enzim eksoprotease $A$. hydrophila tanpa menghambat pertumbuhannya.

Pada penelitian ini, apabila secara kualitatif salah satu jenis ekstrak dapat menghambat produksi enzim eksoprotease tanpa meng-hambat pertumbuhannya maka dilanjutkan dengan uji kuantitatif untuk mengetahui persentase penurunan produksi enzimnya.

\section{Penghambatan Produksi Enzim Eksoprotease Aeromonas hydrophila secara Kualitatif}

\section{Pelarut n-hexan}

Pelarut n-hexan merupakan pelarut nonpolar yang dapat melarutkan senyawa-senyawa metabolit sekunder pada tumbuhan yang bersifat nonpolar. Senyawa metabolit sekunder nonpolar yang terkandung dalam rimpang $C$. xanthorrhiza meliputi minyak atsiri yang terdiri atas 1-cyclo-isoprene myrcene (85\%), aromatic sesquiterpene phenol, dan xanthorrhizol (20\%) (Chu, 2005).

Diameter zona bening dan diameter isolat A. hydrophila dapat dilihat pada Tabel 1. Dari Tabel 1 terlihat bahwa ekstrak rimpang $C$. xanthorrhiza dengan pelarut $n$-hexan pada konsentrasi $2 \%, 4 \%$, $6 \%$, $8 \%$, dan $10 \%$ tidak menghambat produksi enzim eksoprotease dan pertumbuhan $A$. hydrophila. Hal ini dapat dilihat dari tetap terbentuknya zona bening pada medium LB agar di sekitar biakan A. hydrophila, seperti pada Gambar 2.

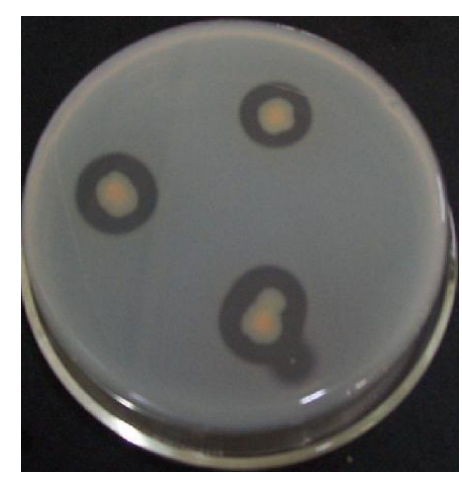

Gambar 1. Produksi enzim eksoprotease menyebabkan terbentuknya zona bening di sekitar biakan A. hydrophila. 


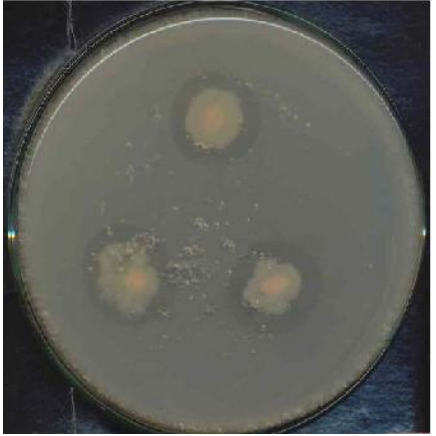

A

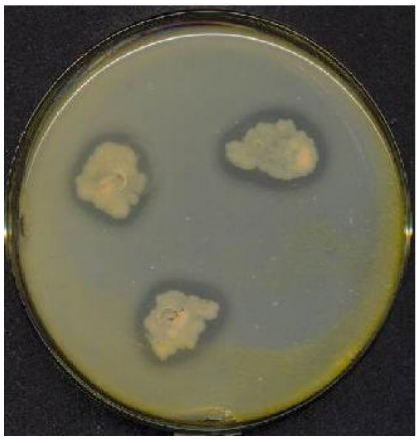

D

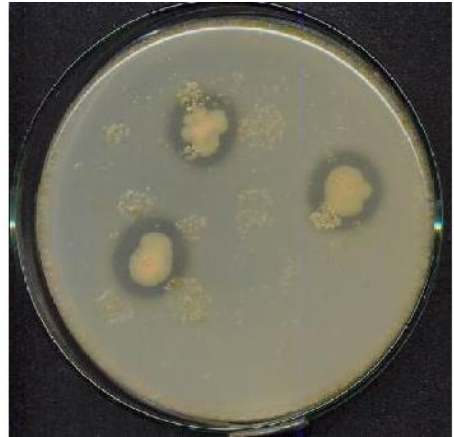

B

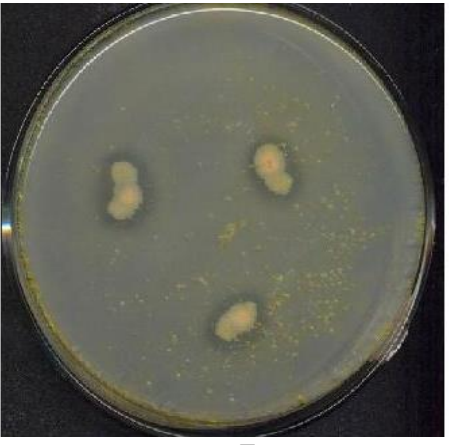

E

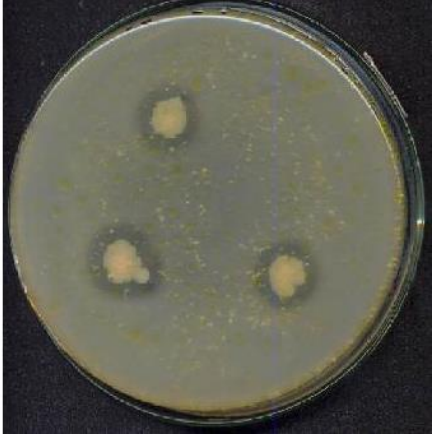

C

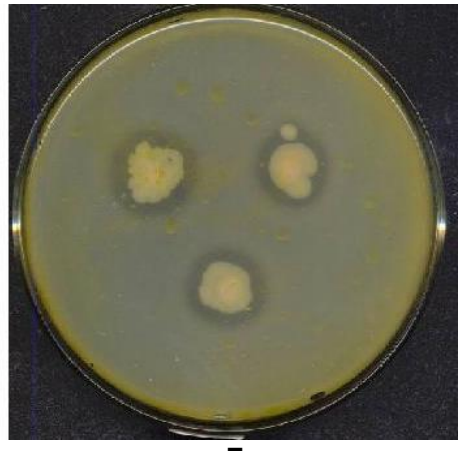

Gambar 2. Penghambatan produksi enzim eksoprotease $A$. hydrophila oleh ekstrak $C$. xanthorrhiza dengan pelarut nhexan. $\mathrm{A}=$ Kontrol positif ( $\mathrm{n}$-hexan), $\mathrm{B}=+2 \%$ ekstrak, $\mathrm{C}=+4 \%$ ekstrak, $\mathrm{D}=+6 \%$ ekstrak, $\mathrm{E}=+8 \%$ ekstrak, dan $\mathrm{F}=$ $+10 \%$ ekstrak

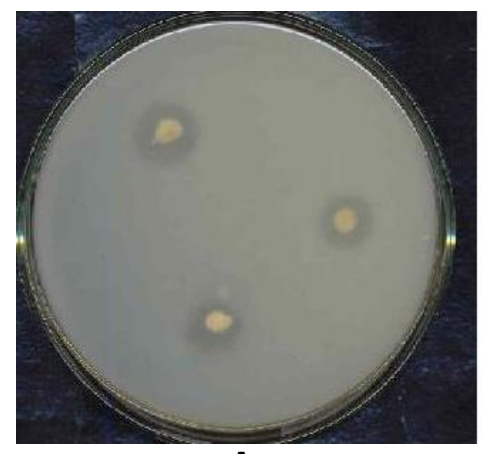

$\mathbf{A}$

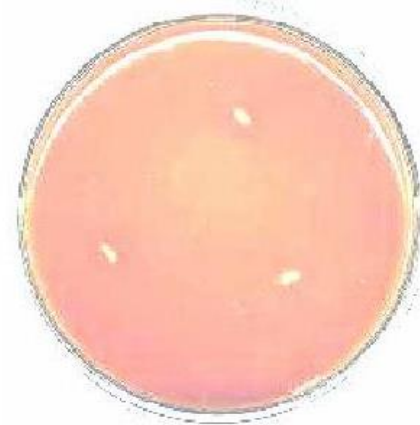

D

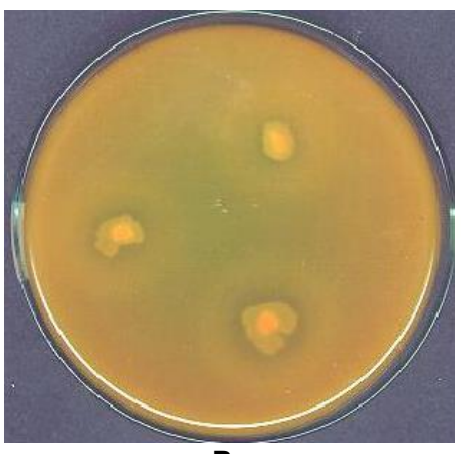

B

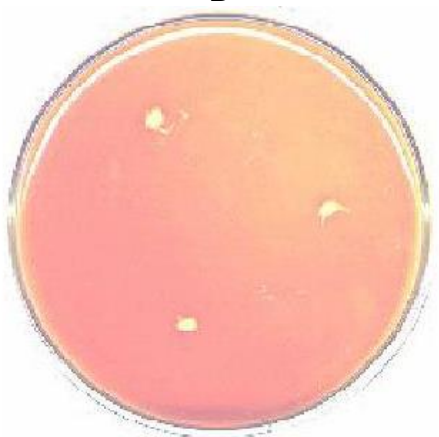

E

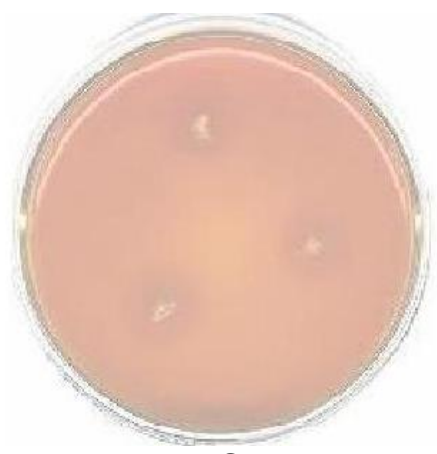

C

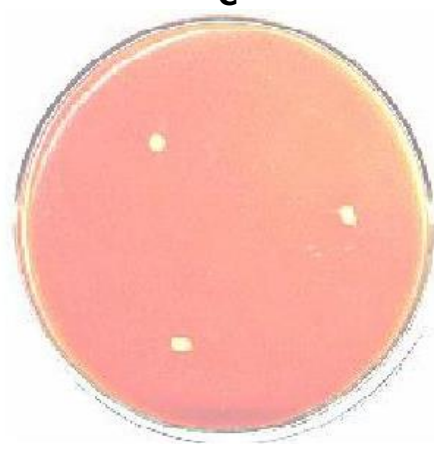

F

Gambar 3. Penghambatan produksi enzim eksoprotease $A$. hydrophila oleh ekstrak $C$. xanthorrhiza dengan pelarut etil asetat. $\mathrm{A}=$ Kontrol (etil asetat), $\mathrm{B}=+2 \%$ ekstrak, $\mathrm{C}=+4 \%$ ekstrak, $\mathrm{D}=+6 \%$ ekstrak, $\mathrm{E}=+8 \%$ ekstrak, dan $\mathrm{F}=$ $+10 \%$ ekstrak 
Dari Gambar 2 terlihat bahwa ekstrak $C$. xanthorrhiza dengan pelarut n-hexan pada konsentrasi $2 \%, 4 \%, 6 \%$, $8 \%$, dan $10 \%$ serta kontrol positif (4\% n-hexan), tidak menunjukkan adanya aktivitas penghambatan produksi enzim eksoprotease $A$. hydrophila. Hal ini dapat diketahui dengan tetap terbentuknya zona bening pada medium LB agar di sekitar biakan $A$. hydrophila. Diameter zona bening paling kecil terbentuk pada pemberian $8 \%$ ekstrak yaitu sebesar $10 \mathrm{~mm}$. Diameter zona bening berkurang karena diameter isolat $A$. hydrophila juga mengalami pengurangan maka dianggap ekstrak rimpang $C$. xanthorrhiza dengan pelarut n-hexan pada variasi konsentrasi $2 \%$ hingga $10 \%$ tidak menghambat produksi enzim eksoprotease dan pertumbuhan $A$. hydrophila, sehingga tidak dilanjutkan pada uji kuantitatif untuk mengetahui persentase penurunan produksi enzim eksoprotease $A$. hydrophila.

Dari hasil penelitian ini diketahui bahwa ekstrak rimpang $C$. xanthorrhiza dengan pelarut $\mathrm{n}$-hexan tidak menghambat aktivitas enzim eksoprotease dan pertumbuhan $A$. hydrophila. Tidak terhambatnya aktivitas enzim eksoprotease dan pertumbuhan A. hydrophila diduga karena senyawa-senyawa aktif nonpolar yang terkandung dalam ekstrak tidak mampu menghambat sistem quorum sensing. Selain itu, ekstrak yang bersifat nonpolar memungkinkan ekstrak tidak dapat larut sempurna dengan medium, sehingga tidak terjadi proses penghambatan aktivitas enzim eksoprotease dan pertumbuhan $A$. hydrophila.

\section{Pelarut Etil Asetat}

Senyawa semipolar yang terkandung dalam rimpang C. xanthorrhiza diantaranya curcumin (62\%) dan desmethoxycurcumin (38\%). Untuk dapat melarut- kan kedua senyawa tersebut, harus dilakukan proses ekstraksi dengan menggunakan pelarut semipolar. Salah satu jenis pelarut semipolar yang biasa digunakan dalam proses ekstraksi adalah etil asetat. Diameter zona bening dan diameter isolat $A$. hydrophila dapat dilihat pada Tabel 2.

Tabel 1. Diameter zona bening dan diameter isolat pada pemberian ekstrak rimpang $C$. xanthorrhiza dengan pelarut $n$-hexan.

\begin{tabular}{ccc}
\hline $\begin{array}{c}\text { Konsentrasi } \\
\text { Ekstrak (\%) }\end{array}$ & $\begin{array}{c}\text { Diameter } \\
\text { Isolat }(\mathbf{m m})\end{array}$ & $\begin{array}{c}\text { Diameter Zona } \\
\text { Bening (mm) }\end{array}$ \\
\hline 0 & 14,8 & 21,0 \\
2 & 14,2 & 18,5 \\
4 & 11,0 & 13,0 \\
6 & 17,5 & 23,5 \\
8 & 10,0 & 12,0 \\
10 & 14,0 & 20,0 \\
\hline
\end{tabular}

Tabel 2. Diameter zona bening dan diameter isolat pada pemberian ekstrak rimpang $C$. xanthorrhiza dengan pelarut etil asetat.

\begin{tabular}{ccc}
\hline $\begin{array}{c}\text { Konsentrasi Diameter Isolat } \\
\text { Ekstrak (\%) }\end{array}$ & $\begin{array}{c}\text { Diameter Zona } \\
\text { Bening }(\mathbf{m m})\end{array}$ \\
\hline 0 & 11,0 & 13,0 \\
2 & 12,5 & 14,0 \\
4 & 7,0 & - \\
6 & 5,0 & - \\
8 & 5,0 & - \\
10 & 5,0 & - \\
\hline
\end{tabular}

Keterangan: - = Tidak terbentuk zona bening
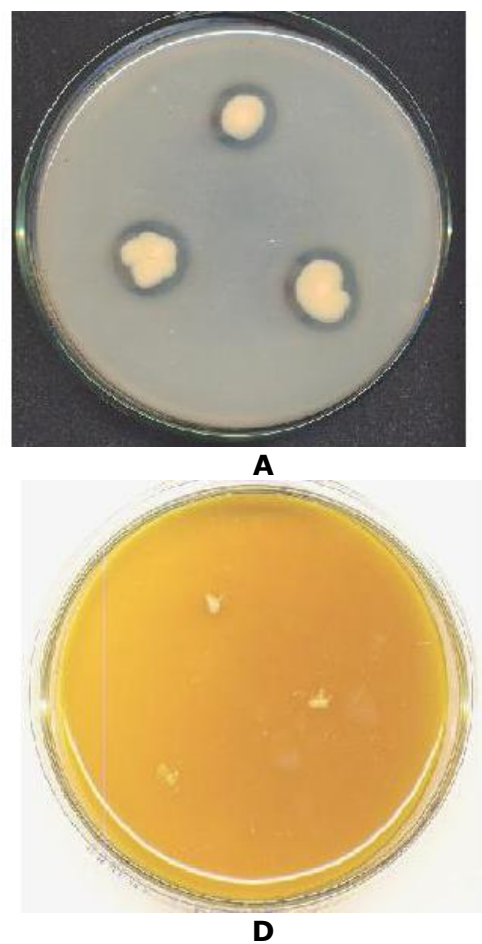

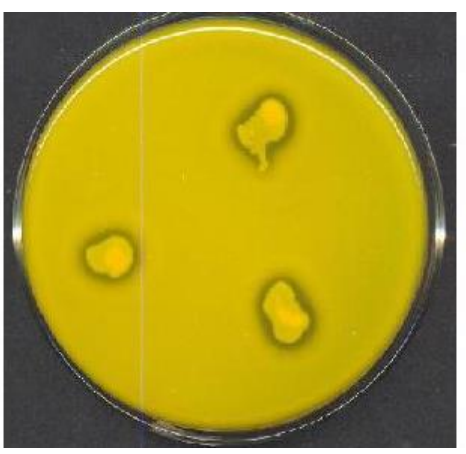

B

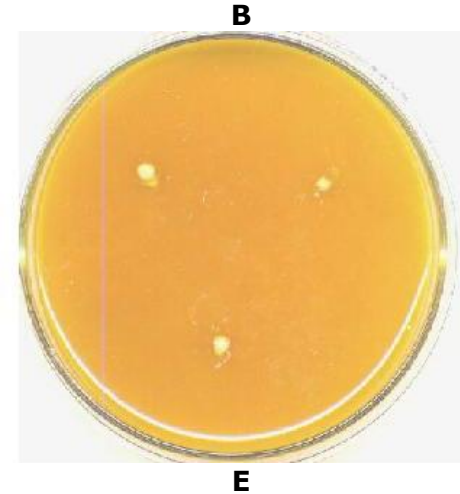

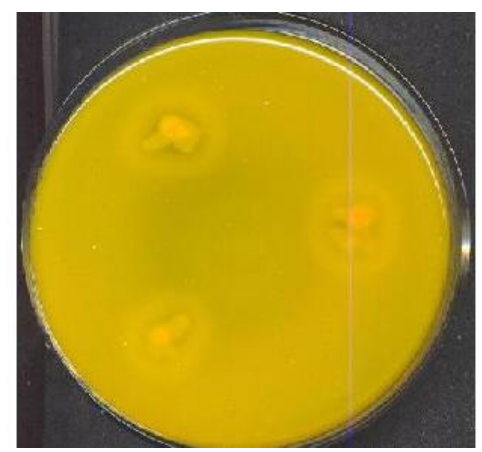

C

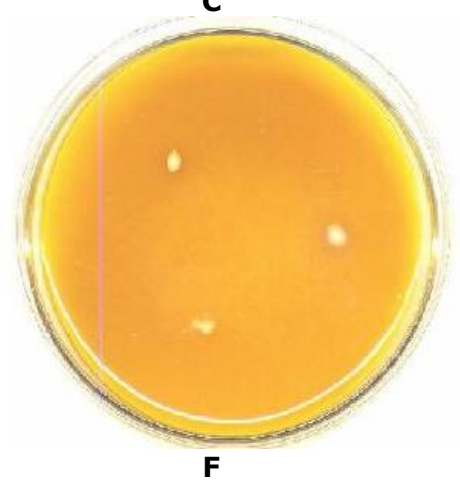

Gambar 4. Penghambatan produksi enzim eksoprotease $A$. hydrophila oleh ekstrak $C$. xanthorrhiza dengan pelarut etanol. $\mathrm{A}=$ Kontrol positif (etanol), $\mathrm{B}=+2 \%$ ekstrak, $\mathrm{C}=+4 \%$ ekstrak, $\mathrm{D}=+6 \%$ ekstrak, $\mathrm{E}=+8 \%$ ekstrak, $\mathrm{F}=+10 \%$ ekstrak. 
Curcuma xanthorrhiza dengan pelarut etil asetat mampu menghambat produksi enzim eksoprotease tanpa disertai penghambatan pertumbuhan. Penghambatan produksi enzim eksoprotease $A$. hydrophila oleh ekstrak rimpang $C$. xanthorrhiza dengan pelarut etil asetat dapat dilihat pada Gambar 3. Dari Gambar 3 dapat dilihat bahwa ekstrak rimpang $C$. xanthorrhiza dengan pelarut etil asetat pada konsentrasi $6 \%, 8 \%$, dan $10 \%$ mampu menghambat pertumbuhan $A$. hydrophila sekaligus menghambat produksi enzim eksoprotease. Terhambatnya pertumbuhan $A$. hydrophila dapat dilihat dari kecilnya diameter koloni yaitu hanya sekitar $5 \mathrm{~mm}$ atau sama dengan diameter isolat awal yaitu sebelum diinkubasi selama 24 jam pada suhu $37^{\circ} \mathrm{C}$, sedangkan penghambatan produksi enzim eksoprotease dapat dilihat dari tidak terbentuknya zona bening di sekitar biakan $A$. hydrophila. Pada konsentrasi $2 \%$, A. hydrophila tetap dapat tumbuh dan memproduksi enzim eksoprotease. Pada konsentrasi $4 \%$, A. hydrophila tetap dapat tumbuh namun tidak terbentuk zona bening.

Penghambatan pertumbuhan dan produksi enzim eksoprotease $A$. hydrophila terjadi seiring dengan peningkatan konsentrasi ekstrak. Hal ini diduga karena senyawa antibakteri yang terkandung dalam ekstrak juga semakin meningkat. Pada konsentrasi $4 \%, A$. hydrophila tetap dapat tumbuh, namun aktivitas enzim eksoprotease mengalami penurunan. Hal ini diduga disebabkan oleh adanya penghambatan sistem quorum sensing yang meregulasi sintesis enzim eksoprotease oleh senyawa metabolit sekunder yang terkandung dalam ekstrak yaitu curcumin. Menurut Rukayadi and Hwang (2004), curcumin dapat menghambat sistem quorum sensing pada Chromabacterium violaceum yang memiliki molekul sinyal berupa C4HSL atau sama dengan molekul sinyal pada $A$. hydrophila. Penghambatan pertumbuhan $A$. hydrophila oleh ekstrak pada konsentrasi $6 \%, 8 \%$, dan $10 \%$, diduga karena adanya curcumin yang juga berperan sebagai senyawa antibakteri. Hasil penelitian yang dilakukan oleh Negi et al. (1999) menunjukkan bahwa curcumin dapat menghambat pertumbuhan Bacillus cereus, Bacillus subtilis, Escherichia coli, dan Pseudomonas aeruginosa.

\section{Pelarut etanol}

Etanol merupakan senyawa yang dapat melarutkan senyawa metabolit sekunder seperti alkaloid, kumarin, antrakinon, dan steroid. Etanol bersifat polar sehingga mampu melarutkan senyawa-senyawa polar pada rimpang $C$. xanthorhiza yang diantaranya adalah zat tepung, gula, dan polisakarida. Diameter zona bening dan diameter isolat $A$. hydrophila dapat dilihat pada Tabel 3. Dari Tabel 3 dapat dilihat bahwa 4\% ekstrak rimpang $C$. xanthorrhiza dengan pelarut etanol mampu menghambat produksi enzim eksoprotease tanpa disertai penghambatan pertumbuhan.
Tabel 3. Diameter zona bening dan diameter isolat pada pemberian ekstrak rimpang C. xanthorrhiza dengan pelarut etanol.

\begin{tabular}{ccc}
\hline $\begin{array}{c}\text { Konsentrasi } \\
\text { Ekstrak (\%) }\end{array}$ & $\begin{array}{c}\text { Diameter } \\
\text { Isolat } \mathbf{( m m )}\end{array}$ & $\begin{array}{c}\text { Diameter Zona } \\
\text { Bening ( mm) }\end{array}$ \\
\hline 0 & 12,0 & 15,0 \\
2 & 11,5 & 14,0 \\
4 & 10,5 & 10,0 \\
6 & 5,0 & - \\
8 & 5,0 & - \\
10 & 5,0 & - \\
\hline
\end{tabular}

Keterangan: - = Tidak terbentuk zona bening

Penghambatan produksi enzim eksoprotease $A$. hydrophila oleh ekstrak rimpang $C$. xanthorrhiza dengan pelarut etanol dapat dilihat pada Gambar 4. Dari Gambar 4 terlihat bahwa pemberian ekstrak rimpang $C$. xanthorrhiza dengan pelarut etanol menyebabkan penghambatan pertumbuhan dan produksi enzim eksoprotease $A$. hydrophila pada konsentrasi $6 \%$, $8 \%$, dan $10 \%$. Penghambatan produksi enzim eksoprotease dapat dilihat dari tidak terbentuknya zona bening di sekitar biakan $A$. hydrophila, sedangkan penghambatan pertumbuhan A. hydrophila dapat dilihat dari tidak bertambahnya diameter isolat $A$. hydrophila yaitu $5 \mathrm{~mm}$ atau sama dengan diameter isolat awal sebelum diinkubasi. Pada konsentrasi 4\%, $A$. hydrophila tetap dapat tumbuh tetapi terjadi penurunan aktivitas enzim eksoprotease, karena diameter zona bening yang terbentuk di sekitar biakan $A$. hydrophila lebih kecil dibandingkan dengan kontrol (etanol), yaitu hanya $10 \mathrm{~mm}$, dan jika dibandingkan dengan diameter zona bening pada kontrol yaitu sebesar $15 \mathrm{~mm}$. Pada konsentrasi $2 \%, A$. hydrophila tetap dapat tumbuh dan tetap memproduksi enzim eksoprotease, sehingga terbentuk zona bening dengan diameter $14 \mathrm{~mm}$ di sekitar biakan bakteri.

Senyawa yang terkandung dalam ekstrak rimpang C. xanthorrhiza dengan pelarut etanol yang diduga dapat menghambat produksi enzim eksoprotease adalah senyawa gula. Menurut Secades and Guijjaro (1999), glukosa dan senyawa gula lainnya dapat menghambat produksi enzim eksoprotease pada Yersinia ruckeri. Produksi enzim eksoprotease pada $Y$. ruckeri juga diregulasi oleh sistem quorum sensing tipe LuxIR.

Penghambatan pertumbuhan dan produksi enzim eksoprotease $A$. hydrophila terjadi seiring dengan peningkatan konsentrasi ekstrak. Hal ini diduga karena senyawa antibakteri yang terkandung dalam ekstrak juga semakin meningkat. Pada konsentrasi $6 \%, 8 \%$, dan $10 \%$, pertumbuhan $A$. hydrophila terhambat. Senyawa antibakteri yang terkandung dalam ekstrak $C$. xanthorrhiza dengan pelarut etanol adalah senyawa gula. Menurut Jawetz et al. (1996), senyawa gula memiliki gugus polar yang dapat menurunkan tegangan permukaan dinding sel bakteri sehingga mengganggu permeabilitas sel bakteri, akibatnya pertumbuhan bakteri menjadi terhambat. 


\section{Penghambatan Aktivitas Enzim Eksoprotease Aeromonas hydrophila secara kuantitatif}

Uji kuantitatif dilakukan untuk mengetahui persentase penurunan produksi enzim eksoprotease A. hydrophila oleh ekstrak rimpang $C$. xanthorrhiza. Terdapat dua macam pengukuran pada uji kuantitatif yaitu pengukuran aktivitas enzim eksoprotease dalam mendegradasi azocasein, dan pengukuran nilai Optical Density (OD) untuk mengetahui pertumbuhan $A$. hydrophila. Uji kuantitatif hanya dilakukan pada perlakuan yang secara kualitatif menunjukkan penghambatan produksi enzim eksoprotease $A$. hydrophila tanpa menghambat pertumbuhannya. Dari uji kualitatif diketahui bahwa $4 \%$ ekstrak C. xanthorrhiza dengan pelarut etil asetat dan etanol mampu menghambat produksi enzim eksoprotease $A$. hydrophila tanpa menghambat pertumbuhannya, sehingga uji kuantitatif hanya dilakukan pada kedua perlakuan tersebut.

\section{Kurva pertumbuhan Aeromonas hydrophila}

Pengukuran pertumbuhan $A$. hydrophila dalam penelitian ini digunakan untuk mengetahui bahwa penghambatan produksi enzim eksoprotease $A$. hydrophila tidak disebabkan karena terhambatnya pertumbuhan $A$. hydrophila. Penghambatan produksi enzim eksoprotease disebabkan oleh terhambatnya sistem quorum sensing yang meregulasi sintesis enzim tersebut oleh senyawasenyawa yang terkandung dalam ekstrak rimpang C. xanthorrhiza, sehingga produksi enzim eksoprotease juga mengalami penurunan.

Pengukuran nilai OD $A$. hydrophila dilakukan pada panjang gelombang $600 \mathrm{~nm}$ dan dilakukan tiap 2 jam sekali selama 24 jam. Dari pengukuran OD diperoleh kurva pertumbuhan seperti pada Gambar 5.

Dari kurva pertumbuhan $A$. hydrophila dapat diketahui bahwa dengan pemberian $4 \%$ ekstrak rimpang $C$. xanthorrhiza dengan pelarut etanol tidak menghambat pertumbuhan $A$. hydrophila meskipun terjadi penurunan nilai OD jika dibandingkan dengan kontrol positif ( $4 \%$ etanol) dan kontrol negatif. Sementara itu, pemberian $4 \%$ ekstrak rimpang $C$. xanthorrhiza dengan pelarut etil asetat menyebabkan pertumbuhan $A$. hydrophila menjadi terhambat jika dibandingkan dengan kontrol negatif, sedangkan pada kontrol positif ( $4 \%$ etil asetat) pertumbuhan $A$. hydrophila terhambat dengan nilai OD relatif sama dari jam ke-0 hingga jam ke-24. Penghambatan tersebut diduga disebabkan senyawa etil asetat dapat menghambat pertumbuhan $A$. hydrophila, sedangkan ekstrak $C$. xanthorrhiza dengan pelarut etil asetat tidak menyebabkan penghambatan pertumbuhan $A$. hydrophila karena kandungan etil asetat pada ekstrak relatif lebih sedikit setelah mengalami proses penguapan dengan rotary evaporator.

Gambar 5 menunjukkan fase-fase pertumbuhan A. hydrophila dengan pemberian $4 \%$ ekstrak rimpang C. xanthorrhiza dengan pelarut etil asetat dan etanol. Secara umum, fase lag terjadi pada jam ke-0 hingga jam ke-2, fase log terjadi pada jam ke2 hingga jam ke-6, dan fase stationer terjadi pada jam ke-6 hingga jam ke-24. Menurut Schlegel and Schmidt (1994), pada fase lag, pertumbuhan bakteri berlangsung lambat karena bakteri harus beradaptasi dengan medium baru. Pada fase log, pertumbuhan bakteri berlangsung cepat karena ketersediaan nutrisi yang cukup. Selanjutnya pada fase stationer, pertambahan jumlah bakteri sangat sedikit karena ketersediaan nutrisi yang semakin terbatas. Kurva pertumbuhan $A$. hydrophila selanjutnya dibandingkan dengan kurva aktivitas enzim eksoprotease $A$. hydrophila, untuk memastikan bahwa penghambatan produksi enzim eksoprotease bukan disebabkan karena terjadinya penghambatan pertumbuhan $A$. hydrophila.
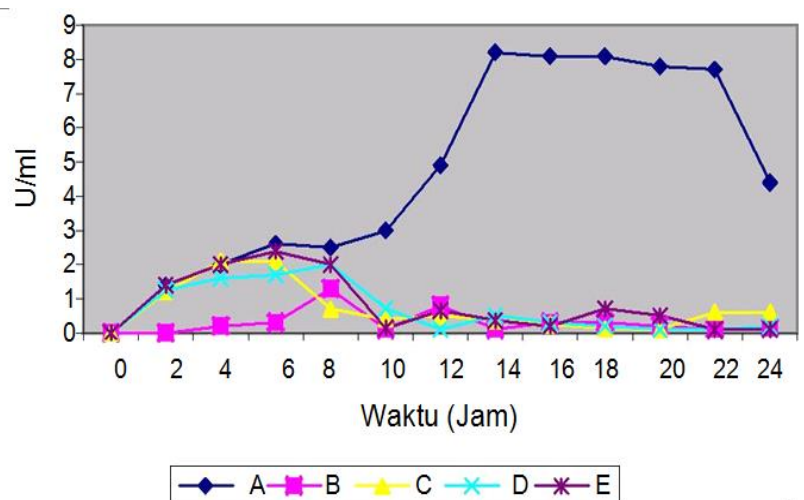

Gambar 6. Kurva produksi enzim eksoprotease $A$. hydrophila. $\mathrm{A}=$ Kontrol negatif (tanpa pemberian pelarut), $B=$ kontrol positif ( $4 \%$ etil asetat), $C=$ kontrol positif $(4 \%$ etanol), $D=+4 \%$ ekstrak $C$. xanthorrhiza dengan pelarut etil asetat, serta $E=+4 \%$ ekstrak $C$. xanthorrhiza dengan pelarut etanol.
Gambar 5. Kurva pertumbuhan $A$. hydrophila selama 24 jam. $\mathrm{A}=$ Kontrol negatif (tanpa pemberian pelarut), $\mathrm{B}=$ kontrol positif ( $4 \%$ etil asetat), $C=$ kontrol positif $(4 \%$ etanol), $D=+4 \%$ ekstrak $C$. xanthorrhiza dengan pelarut etil asetat, dan $E=+4 \%$ ekstrak $C$. xanthorrhiza dengan pelarut etanol 


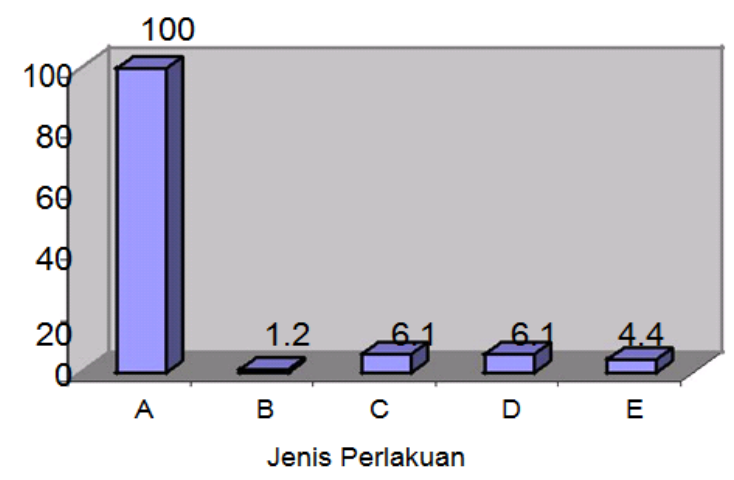

Gambar 7. Persentase produksi enzim eksoprotease $A$. hydrophila pada jam ke-14.

Pengukuran nilai unit aktivitas enzim eksoprotease dilakukan bersamaan dengan pengukuran nilai OD $A$. hydrophila. Dari pengukuran unit aktivitas enzim eksoprotease $A$. hydrophila diperoleh kurva aktivitas enzim eksoprotease $A$. hydrophila seperti pada Gambar 6. Dari Gambar 6, terlihat bahwa produksi enzim eksoprotease baru terdeteksi pada jam ke-2 atau pada saat $A$. hydrophila mengalami fase log, kecuali pada kontrol positif ( $4 \%$ etil asetat) produksi enzim baru terdeteksi pada jam ke-4. Menurut penelitian yang dilakukan oleh O'Reilly and Day (1983), aktivitas proteolitik pada $A$. hydrophila terdeteksi pada saat fase log. Produksi enzim eksoprotease tertinggi terjadi pada jam ke-14, atau pada saat $A$. hydrophila memasuki fase stationer, sedangkan produksi enzim eksoprotease bersifat konstan pada jam ke-14 hingga jam ke-24. Produksi enzim eksoprotease tertinggi terjadi pada saat $A$. hydrophila memasuki fase stationer, hal ini diduga terkait dengan penyediaan nutrisi bagi $A$. hydrophila.

Dari kurva aktivitas enzim eksoprotease $A$. hydrophila dapat dilihat bahwa $4 \%$ ekstrak rimpang C. xanthorrhiza dengan pelarut etil asetat dan etanol dapat menghambat produksi enzim eksoprotease $A$. hydrophila. Hal ini dapat diketahui dari menurunnya nilai unit aktivitas enzim. Penghambatan produksi enzim eksoprotease juga terjadi pada kontrol positif (etil asetat dan etanol). Penghambatan produksi enzim eksoprotease mulai terjadi pada jam ke-8 atau pada saat $A$. hydrophila memasuki awal fase stasioner.

Produksi enzim eksoprotease tertinggi pada kontrol negatif terjadi pada jam ke-14 dan produksi enzim pada jam tersebut dianggap 100\%. Dengan demikian diperoleh persentase penurunan aktivitas enzim eksoprotease dari seluruh perlakuan. Nilai persentase diperoleh dengan membandingkan nilai unit aktivitas perlakuan dengan kontrol kemudian dikalikan $100 \%$. Grafik Persentase produksi enzim eksoprotease $A$. hydrophila pada jam ke-14 dan persentase penurunannya dapat dilihat pada

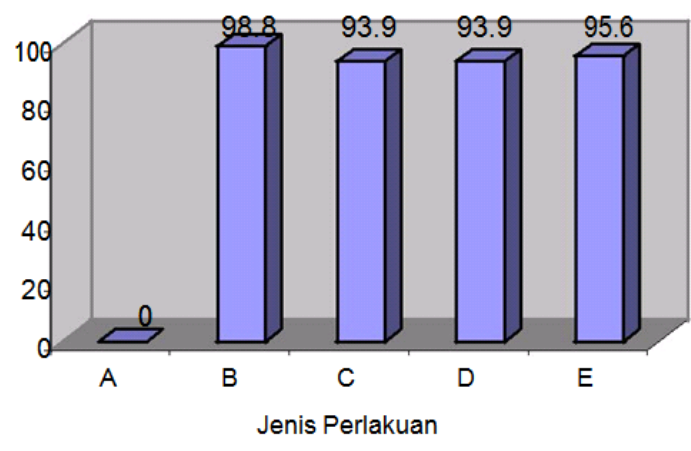

Gambar 8. Persentase penghambatan produksi enzim eksoprotease $A$. hydrophila pada jam ke-14. A = Kontrol negatif (tanpa pemberian pelarut), $B=$ kontrol positif $(4 \%$ etil asetat), $C=$ kontrol positif ( $4 \%$ etanol), $D=+4 \%$ ekstrak $C$. xanthorrhiza dengan pelarut etil asetat, dan $\mathrm{E}=$ $+4 \%$ ekstrak $C$. xanthorrhiza dengan pelarut etanol.

\section{Gambar 7 dan 8.}

Dari Gambar 8 dapat dilihat bahwa penghambatan aktivitas enzim eksoprotease terbesar terjadi pada kontrol positif (4\% etil asetat) yaitu sebesar $98,8 \%$. Aktivitas enzim eksoprotease terhambat diduga karena pertumbuhan $A$. hydrophila juga terhambat. Penghambatan terhadap aktivitas enzim eksoprotease juga terjadi pada kultur A. hydrophila yang ditambah dengan 4\% ekstrak $C$. xanthorrhiza dengan pelarut etil asetat dan etanol tanpa menghambat pertumbuhannya. Persentase penurunannya masing-masing adalah 93,9\% dan 95,6\%.

Pada pemberian $4 \%$ ekstrak C. xanthorrhiza dengan pelarut etanol menyebabkan aktivitas enzim eksoprotease menurun tanpa meng-hambat pertumbuhannnya. Penghambatan produksi enzim eksoprotease juga terjadi pada kontrol positif (4\% etanol). Senyawa-senyawa yang terkandung dalam ekstrak rimpang $C$. xanthorrhiza dengan pelarut etanol yang diduga dapat menghambat produksi enzim eksoprotease $A$. hydrophila adalah gula, polisakarida, dan zat tepung. Menurut penelitian yang dilakukan oleh Secades dan Guijjaro (1999), senyawa glukosa dan senyawa gula yang lain dapat menghambat produksi enzim eksoprotease Yersinia ruckeri. Produksi enzim eksoprotease pada bakteri gram negatif tersebut juga diregulasi oleh sistem quorum sensing tipe LuxIR. Penghambatan produksi enzim eksoprotease juga terjadi pada kontrol positif ( $4 \%$ etanol), sehingga diduga ada pengaruh pelarut terhadap proses penghambatan produksi enzim eksoprotease $A$. hydrophila. Menurut Katri et al. (2003), etanol dan erythromycin atau kombinasi keduanya dapat menghambat produksi pyocynin, protease, hemolisin, dan lektin pada Pseudomonas aeruginosa. Produksi keempat senyawa tersebut juga diregulasi oleh sistem quorum sensing.

Pada kontrol positif ( $4 \%$ etil asetat), produksi enzim mengalami penurunan sebesar 98,8\% dibandingkan dengan kontrol negatif. Produksi enzim eksoprotease menurun diduga karena pertumbuhan $A$. hydrophila juga terhambat, 
sedangkan pada penambahan $4 \%$ ekstrak $C$. Xanthorrhiza, pertumbuhan $A$. hydrophila tidak terhambat, namun aktivitas enzim eksoprotease menurun sebesar 93,9\% jika dibandingkan kontrol negatif. Penurunan aktivitas enzim eksoprotease $A$. hydrophila diduga disebabkan adanya senyawa curcumin pada ekstrak. Menurut Rukayadi and Hwang (2004), curcumin mampu menghambat sistem quorum sensing pada Chromabacterium violaceum meskipun mekanisme penghambatannya belum diketahui.

\section{KESIMPULAN}

Terdapat penghambatan produksi enzim eksoprotease $A$. hydrophila oleh 4\% ekstrak rimpang $C$. xanthorrhiza dengan pelarut etil asetat dan etanol. Ekstrak yang memiliki kemampuan terbesar dalam menghambat produksi enzim eksoprotease adalah ekstrak rimpang $C$. xanthorrhiza dengan pelarut etanol yaitu sebesar $95,6 \%$, meskipun demikian diduga terdapat pengaruh pelarut terhadap penghambatan produksi enzim tersebut.

Diharapkan ada penelitian lebih lanjut untuk mengetahui senyawa pada ekstrak C. xanthorrhiza yang berperan dalam menghambat aktivitas enzim eksoprotease serta analisis ekspresi gen untuk mengetahui secara pasti mengenai adanya penghambatan produksi enzim eksoprotease $A$. hydrophila oleh ekstrak C. xanthorrhiza.

\section{DAFTAR PUSTAKA}

Afrianto, E. dan E. Liviawaty. 1992. Pengendalian Hama dan Penyakit Ikan. Yogyakarta: Kanisius.

Angka, S.L. 2001. Studi Karakterisasi dan Patologi Aeromonas hydrophila Pasa Ikan Lele Dumbo (Clarias gariepinus). Makalah Falsafah Sains. Bogor: Institut Pertanian Bogor.

Chu, J.H.K. 2005. Curcuma xanthorrhiza. http://www.thedao.com/ temulawak.htm.

De Kievit, T.R. and B.H. Iglewski. 2000. Bacterial quorum sensing in pathogenic relationship. Infection and Immunity 68: 4839-4849.

Ellis, A.E., T.S. Hasting, and A.L.S. Munro. 1981. The role of Aeromonas salmonicida extracellular product in the pathology of furunculosis. J. Fish. Dis. 4: 41-51.

Harmani, M.J. Djas, dan N. Said. 2001. Penapisan hayati antimikrobial ekstrak buah pisang batu (Musa brachicarpa). Jurnal Natural 1(1): 34-37.

Hanlon, G. and N.A. Hodges. 1981. Bacitracin and protease production in relation to sporulation during exponential growth of Bacillus licheniformis on poorly utilized carbon and nitrogen sources. J. Bacteriol. 162(2): 427-431.

Hentzer, M. and M. Givskov. 2003. Pharmalogical inhibition of quorum sensing for the treatment of chronic bacterial infection. J. Clint. Invest. 112: 1300-1307.

Jawetz, E., J. Melnick, and E. Adelberg. 1996. Mikrobiologi Kedokteran. Jakarta: Penerbit Buku Kedokteran EGC.

Katri, N.M., N. Garber, N. Gilboa-Garber. 2003. Submic erythromycin-ethanol combination effect on
Pseudomonas Aeruginosa virulence in absence and presence of choline. Abstract of The Second Annual Meeting of The Israel Association of Veterinary Microbiology and Immunology 59: 1-2.

Leung, K.Y. and R.M.W. Stevenson. 1988. Tns-induced protease dericient strains of Aeromonas hydrophila with reduced virulence for fish. Infect. Immun. 56: 2639-2644.

Lewis, K. 2001. Riddle of biofilm resistance. Antimicrob. Agents. Chemother. 45: 999-1007.

Murray, R.K., D.K. Granner, P.A. Mayes, V.W. Rodwell. 1997. Biokimia (Diterjemahkan oleh: Hartono, A.). Jakarta: Penerbit Buku Kedokteran EGC.

Negi, P.S., G.K. Jayaprakasha, L.J.M. Rao, and K.K. Sakhariah. 1999. Antibacterial activity of turmeric oil: A by product from curcumin manufacture. J. Agric. Food. Chem. 47(10): 4297-4300.

Noga, E.J. 1995. Fish desease: Diagnosis and treatment. Missouri: The C.V. Mosbi Company.

O'Reilly and D.F. Day. 1983. Effect of cultural conditions of protease production by Aeromonas hydrophila. Appl. Environ. Microbiol. 45(3): 1132-1135.

Peters, L., G.M. Konig, A.D. Wright, R. Pukall, E. Stackebrandt, L. Eberl, and K. Riedel. 2003. Secondary metabolites of Flustra foliacea and their influence on bacteria. Appl. Environ. Microbiol. 69(6): 3469-3475.

Poernomo, A.T. dan D.A. Purwanto. 2001. Karakterisasi Enzim Proteolitik Bacillus subtilis FNCC 0059. Surabaya: Universitas Airlangga.

Rice, S.A., M. Givskov, P. Steinberg, and S. Kjelleberg. 1999. Bacterial signal and antagonist: The interaction between bacteria and higher organism. J. Mol. Microbiol. Biotechnol. 1(1): 23-31.

Robert, R.J. 1993. Motile septicemia. In: Inglis, V., R.J. Robert, and N.R. Bromage. Bacterial Disease of Fish. Boston: Blackwell Scientific Publications.

Rukayadi, Y. and J.K. Hwang. 2004. Inhibition of quorum sensing for the conol of bacterial infection. Buku Panduan dan Kumpulan Abstrak Pertemuan IImiah Tahunan Perhimpunan Mikrobiologi Indonesia.

Schlegel, H.G. and K. Schmidt. 1994. Mikrobiologi Umum. Yogyakarta: Gadjah Mada University Press.

Shotts, E.B., T.C. Hsu, and W.D. Waltman. 1985. Extracellular proteolytic activity of Aeromonas hydrophila complex. Fish Pathology 20: 37- 44.

Secades, P. and J.A. Guijarro. 1999. Purification and characterizatio of an extracellular proteases from the fish pathogen Yersinia ruckeri and effect of culture conditions on production. Appl. Environ. Microbiol. 65(9): 3969-3975.

Suwanto, A. 2005. Strategi Baru Mengendalikan Penyakit Infeksi. http:// www.kompas.com/kompascetak/0211/081/iptek/mema36.htm.

Swann, L.D. \& White, M.R. 1991. Diagnosis and treatment of Aeromonas hydrophila infection of fish. Urbana, IL: Illinois-Indiana Sea Grant Program.

Swift, S., A.V. Karlyshev, E.L. Durant, M.K. Winson, S.R. Chhabra, S. Macintyre, and G.S. Stewart. 1997. Quorum sensing in Aeromonas hydrophila and Aeromonas salmonicida: Identification of the LuXRI homologs AhyRI and AsaRI and their cognate N-AcylHomoserine Lactones signal molecules. J. Bacteriol. 179(17): 5271-5281.

Swift, S., M.J. Lynch, L. Fish, D.F. Kirke, J.M. Tomas, G.S.A.B. Stewart, and P. Williams. 1999. Quorum sensing-dependent regulation and blockade of eksoprotease production in Aeromonas hydrophila. Infect. Immun. 4: 18-28. 